\title{
A Summary of Studies on Organizational Legitimacy
}

\author{
Yuanyou Tang \\ School of Business Administration, South China University of Technology, Guangzhou, China \\ Email: 826120878@qq.com
}

How to cite this paper: Tang, Y.Y. (2017) A Summary of Studies on Organizational Legitimacy. Open Journal of Business and Management, 5, 487-500. https://doi.org/10.4236/ojbm.2017.53042

Received: June 6, 2017

Accepted: July 8, 2017

Published: July 11, 2017

Copyright (C) 2017 by author and Scientific Research Publishing Inc. This work is licensed under the Creative Commons Attribution International License (CC BY 4.0).

http://creativecommons.org/licenses/by/4.0/

\begin{abstract}
In recent years, more and more scholars have begun to explore the influence of institutional factors on the production and operation of the organization, and formed a new research perspective-institutional basis, and organizational legitimacy is the "core concept" of the new institutionalism theory. This article through the domestic and foreign related literature, systematically expounded the basic issues of organizational legitimacy, research perspective, dimension division and so on, in order to deepen knowledge and understanding of the organization's legitimacy.
\end{abstract}

\section{Keywords}

Institutional Theory, Organizational Legitimacy, Research Review

\section{Introduction}

The early scholars of management regarded the organization as a "rational system", where the organization and the surrounding environment had very precise boundaries, and the business was planned to follow the pre-planned operations (Scott, 1987). The "open system" school objections, that the boundary between the organization and the outside world is not clear, but interrelated. Further, the institutional school emphasizes the evolution of the organization not only from the financial, technical and other aspects of pressure, but also from the social and cultural norms, symbols, beliefs and customs, etc. [1]. For example, in the transition and upgrading system environment, in promoting the "public entrepreneurship, innovation" slogan, the entrepreneurial activity reached an unprecedented height, but the survival rate of new enterprises is very low; it will be difficult to explain from the angle of "economic man" assumption. Institutional scholars believe that the new entry defects and the resulting legitimacy threshold are an important reason for the high mortality rate of enterpris- 
es [2]; this view and perspective have been recognized by the academic community, and the reason why such a cognitive change is due to "legitimacy" boarded the stage of history and is carried out by the relevant research [3]. Although Weber introduced "legitimacy" into organizational sociology, it was not until 1995 that western academics began to systematically study it [3] [4]. In China, although the study of the legitimacy of the organization has been widespread, it is not deep enough. Therefore, the "legitimacy" of the relevant proposition is not understood enough. Based on this, this article sorts out and deepens their understanding of the "legitimacy" through the new system theory of legitimacy literature.

\section{The Emergence and Development of Institutional Theory}

There are three pillars in the field of strategic management, namely, the Market-Based View, the Resource-Based View and the Institutional-Based View. The concept of market orientation is the first to draw attention, which is due to the development of industrial organization theory. In the 1930s, Mason and Bain put forward the SCP analysis paradigm of industrial organization theory, and the Market-Based View was formed. The core view was that the industrial structure theory had a great influence on the development of the enterprise. The choice of the enterprise industry market has a decisive role in the future of the enterprise. If the industry and the market are wrong, it is difficult for the enterprise to achieve the expected benefits and vision. However, in practice, scholars have gradually found why in the same industry, some companies develop well, some companies are in critical condition? Based on this, Wernerfelt formally put forward the Resource-Based View [5], so that the enterprise development-related research perspective from the market perspective to the concept of ResourceBased View, academics believe that the strategic resources within the enterprise and unique ability is the key to the survival and development of enterprises, but not all of the resources of enterprises can be converted into the core competitiveness. Only when the resources to meet the value, scarcity, irreplaceability and difficult to imitate when they can become a tool in the market competition. Then, some scholars pointed out that the role of the environment can not be ignored, the dynamic changes in the external environment has an important impact on the enterprise. The system environment has strong binding force and influence on all aspects of enterprise production and management [6]. Later, more and more scholars focused on the study of the institutional environment, and Peng's series of research first introduced the system elements into the strategic management of enterprises, and laid the Institutional-Based View in the strategic management of the historical position [7]. Peng in 2002 also formally put forward the institutional basis of the concept can be with the resource base concept, the market based on the view of the same level, so far, strategic management "three pillars" situation shaping [8]. Resource-based view that the internal resources of enterprises is the basis for a series of choices, and strategic institutional basis view that the strategy needs to meet the expectations of internal and 
external stakeholders to ensure that the strategy is legitimate [9].

However, the development of institutional theory is not smooth sailing, but also experienced many setbacks, which at the beginning of a little suffered cold, or even not to be seen. As early as 1962, Chandler pointed out in his book "Strategy and Structure" that the basis for corporate strategy is to adapt to the environment and therefore must be developed on the basis of an analysis and evaluation of the environment. However, for the next fifteen years or so, the institutional elements of the environment have not been taken seriously. 19621977 was the prevailing period of the old institutionalism theory. Although few scholars pointed out the importance of the system in this period, it was not explored deeply, the maximization of efficiency advocated by economists and the extreme dominance of extreme utilitarianism, according to the representative of the old institutionalist school Van Buren (1983) pointed out that the system is essentially a person or society on some of the relationship or some of the role of the general thinking habits, and the system attributed to a popular mental state [10]. And this passive situation until 1977 was finally broken. In 1977, Meyer \& Roman first proposed the new institutionalism theory [11], after each scholar is mainly divided into two factions, one is the North as the representative of the economic school, the main study is the efficiency of different system selection [12]. The other is based on Scott as the representative of the sociology of the organization, the main research is the legitimacy of the system and the system itself [13]. Williamson $(1975,1985)$ argues that institutional differences will lead to different transaction costs, and that an efficient institutional environment will gradually replace inefficient institutional environments [14] [15]. Since then, the representative of the school of the North defined the system as a constraint to organizational behavior and the relationship between the zero-sum game, the institutional environment is more like a linear programming constraints, in a series of conditions to achieve maximum efficiency [16]. The representative of the sociology, Scott, emphasizes that the system is a regular, normative and cognitive framework and activity that not only constrain the behavior of enterprises, but also guide the behavior of enterprises. North divides the system into formal and informal systems, including the relevant laws and norms, which include sanctions, taboos, customs, traditions and codes of conduct. He also believes that the environment is the decisive factor in the efficiency of economic organizations. [17]. However, the definition of institutional sociology is clearly broader than that of the North, For example, Hall \& Taylor points out that the system not only covers laws, norms, traditions and customs, but also regulators, as well as moral templates, cognitive templates, and symbolic systems that provide meaningful frameworks for human action [18]. Scott divides the system into the system of regulation, normative system and cognitive system. The regulation is the pillar of formal system, and the informal system is based on norms and cognition [4].

\section{Legitimacy Definition}

Legitimacy is the core concept of the new institutionalism theory. The legitimacy 
mechanism is the most important mechanism of the new institutionalism theory. The basic idea is: the social legal system, cultural expectations, the concept of the system, once become widely accepted by the social facts, it has a strong power, restrain and regulate people's behavior. Weber is considered to be the first scholar to introduce legitimacy into sociological research (Johnson et al., 2006; Ruef \& Scott [19], 1998; Suchman [3], 1995). Weber argues that organizational legitimacy is that organizational activity is consistent with organizational rules and structures [20]. It is critical to emphasize that the organization is consistent with universal values and "motto"-that legitimacy comes from consistency with social rules, norms and laws. Then, a large number of scholars discussed the definition of legitimacy, such as: Parsons $(1956,1960)$ on the basis of Weber's view, extended the connotation of legitimacy: Organizational legitimacy is the consistency of organizational values with the values of the organization's embedded social context [21]. Maurer (1971) points out that legitimacy is a process that is the process by which the organization gives power to its partners or superior systems [22]. Dowling \& Pfeffer (1975) defines legitimacy as "social values associated with business activities consistent with accepted behavioral norms in larger social systems" [23]. Meyer \& Rowan (1977) tied legitimacy to resources, believing that both are more efficient than the old institutional theorists, and that they need to be consistent with the institutional environment. Meyer \& Rowan (1977), Zucker (1977), although only talking about legitimacy and did not define the legitimacy of the law, but the organization of legitimacy research to enhance a level, directly or indirectly to promote the rise of the new institutionalism [24]; Meyer \& Scott (1983) proposed organizational legitimacy is a degree of cultural organizations have been supported-external culture of the organization's existence, function, value, power, and so there is absolutely no alternative explanation. A legitimate organization is an organization that does not have a problem, its goals, methods, resources, and control systems are necessary, clear, complete, irreplaceable [25]. The legitimacy given by Knoke (1985) is that an organization has the power to act on its strategic choice, which is universally accepted by the community [26].

There are a lot of definitions about legitimacy,can be said that different people have different views. Some scholars believe that legitimacy from the negative definition may be better understood, such as Pfeffer \& Salancik (1981) pointed out: when the behavior was found to be illegal, then the next will be Attack! [27]. However, the academic community is still talking about each other, there is no awareness of the consistency of legitimacy, which greatly hindered the development of institutional theory. Some scholars have studied more than 20 years of research and found that the academic community described more about legitimacy than defined (Terreberry, 1968, suchman, 1995) [3] [28]. Until 1995, Suchman published in the Academy of Management Review "Managing legitimacy: Strategic and institutional approaches" article, for the previous study is often only part of the legitimacy of some of the limitations, given a broad definition: Legitimacy is the enterprise stakeholders to the existing system of laws, 
rules, norms, values, beliefs as the evaluation criteria for corporate activities appropriate, proper and desirable in general perceived or envisaged [3]. This definition has been widely recognized by academia, which has laid the definition of organizational legitimacy in one fell swoop and has had a profound impact on future research. Throughout the previous explores the definition of legitimacy, we can easily find that although Weber early on the "legitimacy" into the organizational sociology, but until 1995, it has a consistent understanding, which is not difficult to understand why in 1995 the western academic circles began to systematically study the legitimacy [3] [4]. The definition of legality can be summarized as Table 1.

The study of the new institutionalism theory scholars attach great importance to legitimacy, they believe that the face of legitimacy requirements, the organization can only sacrifice part of the performance of the cost, in exchange for the necessary legitimacy [6] [11], more scholars mentioned because of lack of legitimacy, the ability of an organization to pursue its goals and the ability to accumulate resources will be greatly reduced, and even lose the foundation of survival [29] [30], Elsbach (1994) considers necessary to attach importance to the legitimacy of the constraints posed by the system pressure to shape the role of the organization, to obtain legitimacy remains the foundation of the survival and development of the organization [31]. Since legitimacy is so important, who will judge me unlawful? What are the indicators of judgment? How can I get legitimacy? Davis et al. (2000) pointed out that the institutional environment in which the organization is located is filled with requests and specifications from various stakeholders, and therefore, as a member of the environment, in order to obtain the support of stakeholders, especially the support of key stakeholders to obtain organizational legitimacy, it must be based on the majority of the mem-

Table 1. Legitimacy definitions.

\begin{tabular}{|c|c|c|c|c|}
\hline \multirow{10}{*}{$\begin{array}{l}\text { Legitimacy } \\
\text { definition }\end{array}$} & \multirow{9}{*}{$\begin{array}{c}\text { Positive } \\
\text { definition }\end{array}$} & \multirow{3}{*}{$\begin{array}{l}\text { The process of } \\
\text { giving power }\end{array}$} & Maurer (1971) & $\begin{array}{l}\text { Legitimacy is a process that is the process by which an } \\
\text { organization gives power to its partner or superior system }\end{array}$ \\
\hline & & & $\begin{array}{l}\text { Meyer \& Rowan } \\
\qquad(1977)\end{array}$ & $\begin{array}{l}\text { The legitimacy and the resources side by side, that both are not just as } \\
\text { old institutional theory scholars say as the efficiency of its core, and } \\
\text { the need to have consistency with the institutional environment }\end{array}$ \\
\hline & & & Knoke (1985) & $\begin{array}{l}\text { Is an organization has its strategic choice to start the power of action, this power } \\
\text { by the public "generally accepted" }\end{array}$ \\
\hline & & \multirow{6}{*}{$\begin{array}{l}\text { Maintain } \\
\text { consistency }\end{array}$} & Parsons & Organizational legitimacy is the consistency of organizational values \\
\hline & & & $(1956,1960)$ & with the values of the organization's embedded social context \\
\hline & & & Dowling \& & Social values associated with business activities are consistent \\
\hline & & & Pfeffer (1975) & with accepted behavior in larger social systems \\
\hline & & & Meyer \& Scott (1983) & $\begin{array}{l}\text { Organizational legitimacy is the degree to which an organization } \\
\text { receives cultural support }\end{array}$ \\
\hline & & & Suchman (1995) & $\begin{array}{l}\text { Legitimacy is the enterprise stakeholders to the existing system of laws, rules, } \\
\text { norms, values, beliefs as the evaluation criteria for corporate activities } \\
\text { appropriate, proper and desirable in general perceived or conceived }\end{array}$ \\
\hline & $\begin{array}{l}\text { Negative } \\
\text { definition }\end{array}$ & & $\begin{array}{c}\text { Pfeffer \& } \\
\text { Salancik (1981) }\end{array}$ & When the act is considered illegal, then it will be attacked! \\
\hline
\end{tabular}

Source: Author finishing. 
bers of the institutional environment recognized by the industry norms or rules for their own code of conduct [32]. There are also scholars in the country made a similar point of view, such as Song Tiebo (2013) pointed out that members of society need to be observed by their own structure or behavior by the community, and members of the community perceived by the structure and behavior and system requirements are consistent, in order to obtain legitimacy [33].

However, a systematic exposition of these questions and answers is oliver, she proposed $5 \mathrm{c}$ model, that is the cause, constitute, content, control, context five kinds of system. The relationship between the factor and the firm's strategic response behavior as shown in Table 2 .

\section{Exploring the Two Perspectives of Organizational Legitimacy}

Because of the legitimacy of the organization, the organization and the external environment are so closely linked, and some scholars in the strategic direction of the enterprise begin to use this concept to interpret the strategic behavior of the organization [31] [34]. Thus, there are two research perspectives-institutional legitimacy and strategic legitimacy, both of which are interrelated and differentiated.

\subsection{Institutional Legitimacy Perspective}

The perspective of institutional legitimacy adopt a passive attitude toward legitimacy, and legitimacy will be seen as an ideological notion of constraint. That organizational legitimacy is the product of the system [6], is the social solidification of faith, only in line with the behavior of belief have the legitimacy to speak. The behavior of the subject "deeds" releases the information that is judged by the stakeholders, and the objective information gives the organization the corresponding legitimacy [35]. Based on this, companies bear the brunt need to make themselves look reasonable, other resources in the process of access to this

Table 2. The relationship between institutional factors and corporate strategic response behavior.

\begin{tabular}{|c|c|c|}
\hline $\begin{array}{l}\text { Institutional } \\
\text { elements }\end{array}$ & research problem & Institutional Factors and Strategic Response \\
\hline Cause & $\begin{array}{l}\text { Why the organization will be forced to obey } \\
\text { the rules and expectations of the system }\end{array}$ & $\begin{array}{l}\text { And the system pressure to keep the amount of expected social legitimacy, the } \\
\text { lower the economic benefits, the greater the likelihood of resistance }\end{array}$ \\
\hline Constituents & Who put pressure on the organization & $\begin{array}{l}\text { The higher the diversity of the constituent, the lower the degree of external de- } \\
\text { pendence on the source of the system, the greater the likelihood of resistance }\end{array}$ \\
\hline Content & $\begin{array}{l}\text { What rules and requirements the } \\
\text { organization is compelled to comply with }\end{array}$ & $\begin{array}{l}\text { Institutional standards or requirements with the institutional objectives of the } \\
\text { lower degree of consistency, the greater the arbitrariness of organizational con- } \\
\text { straints, the greater the likelihood of resistance }\end{array}$ \\
\hline Control & $\begin{array}{l}\text { How the system pressure or how to put } \\
\text { pressure }\end{array}$ & $\begin{array}{c}\text { Institutional standards, the degree of mandatory law behind the requirements, the } \\
\text { lower the degree of spontaneous spread, the greater the possibility of institutional } \\
\text { resistance to institutional pressure }\end{array}$ \\
\hline
\end{tabular}

Source: According to Oliver C. Strategic responses to institutional processes. Academy of management review, 1991, 16 (1): $145-179$. 
goal will be a matter of course, is a derivative by-product. According to the legitimacy of the system, enterprises will accept the legitimate behavior and related forms, but do not care whether the operation efficiency of the enterprise has improved [41]. Obviously, from the perspective of institutional legitimacy, the organization of the field of enterprises under the pressure of the institutional environment, forcing the final behavior of members of the field tend to be consistent [36]. According to Dimaggio \& Powell (1983), the organization obtains legitimacy by coercive conformal, normative isomorphism and mimicry [6]. Coertive isomorphism refers to the institutional pressure generated by the interdependence of the organization. The leading enterprises in the field often rely on their own strong strength to influence other individual behaviors; Normative isomorphism is based on the requirements of various professional organizations in the organization field. Memetive isomorphism refers to the fact that enterprises are faced with the uncertainty of the environment, in order to avoid risks and reduce stress, imitate the results of the benchmark companies within the organization.

However, the legitimacy research based on institutional perspective has been widely criticized as hanging in the air and can not land, lack of micro-foundation (Cao Zhenghan, 2005) [37]. There is no way to measure and manipulate legitimacy because there is no micro mechanism in the formation and evolution of legitimacy in a specific field [38]. Therefore, there is no way to measure and manipulate the legitimacy. Based on this, the research on the micro mechanism of organizational legitimacy is urgent and becomes a hot spot. Until a number of management scholars introduced the concept of legitimacy into the field of management research, the use of strategic vision of the legitimacy of the organization as an important resource, the legitimacy of the study from the initial "retreat" to "pragmatic" change.

\subsection{Strategic Legitimacy Perspective}

With the transfer of legitimacy from the institutional perspective to the strategic perspective, the academic community takes a more proactive approach to legitimacy. Some scholars have begun to pay attention to the organization to obtain legitimacy, can improve the ability of enterprises to absorb and access to resources [39], and of great significance to the enterprises' survival and development [11] [25] [40] [41]. Thus, legitimacy is regarded as a strategic resource, and strategic schools focus on the initiative of the enterprise itself [41]. That legitimacy is an "important resource that can help the organization acquire other resources" [42]. Strategic legitimacy is different from the institutional legitimacy because of initiative to play, so in the face of legitimacy constraints, why the initiative has the possibility to play? A very important reason is that under the influence of multiple institutional pressures in the field, the intensity of institutional constraints in the field is reduced. Different interests of the individual expectations of the enterprise is not the same or even a large difference, resulting in the organization may face a variety of stakeholders from the multiple 
system pressure, requires different and even demands that the exact opposite of the system pressure greatly dilutes the strength of the legality of the field constraints, provides the opportunity for the organization to play a subjective initiative!

\section{Division of Legitimacy Dimension}

The division of the dimensions of organizational legitimacy is the focus of research on organizational legitimacy. In 1986, singh first divided the legitimacy into the internal legitimacy and external legitimacy [43], internal legitimacy refers to the internal members of the organization to coordinate their role in the organization, external legitimacy refers to the external grant organization identity or status [43]. The sources of external legitimacy include government, trade unions, licensing agencies, subvented organizations, public opinion and media, intellectuals, professional organizations, business. The sources of internal legitimacy include managers, employees, board members, personnel experts and so on. Aldrich \& Fiol (1994) first divides legitimacy into two dimensions: social and political legitimacy and cognitive legitimacy [44], according to the different sources of legitimacy constraints faced by start-ups. On this basis, Scott (1995) further divides socio-political legitimacy into regulative legitimacy and normative legitimacy. Regulatory legitimacy refers to "doing things correctly", from the industry associations, governments, professional organizations and other departments to develop a variety of laws and norms. Normative legitimacy specifically refers to "doing the right thing", also known as moral legitimacy, from the universal values and morality of society, reflecting the public on the enterprise "to do the right thing" is expected. The values and morals here mean that the market competition includes values, beliefs and norms that are shared by all stakeholders [45]. Cognitive legitimacy emphasizes what is understood and accepted by people, especially "universally accepted", which is similar to the "categorization" of strong legitimacy levels, reflecting the degree of coincidence between the organization's activities and the "Taken for granted" rule [6]. Cognitive legitimacy has two connotations: the first layer of connotation refers to the legitimacy of the establishment of the premise is "understanding", That is, stakeholders believe that the behavior of enterprises is appropriate, can be understood and accepted, people trust the action taken by the enterprise. Another meaning is "take for granted", that is, all stakeholders categorically that the organization should take such behavior, without any reason, this cognitive paradigm has long been deeply rooted in the stakeholders themselves values, and this "justified" belief is the most important source of cognitive legitimacy.

We need to note that Scott's division of the main concern is the external stakeholders (that is, the government, the public, upstream and downstream enterprises) on corporate behavior awareness and evaluation.

Suchman divides socio-political legitimacy into moral legitimacy and pragmatic legitimacy on the basis of Scott's classification and Aldrich \& Fiol's (1994) 
classification. Practical legitimacy is based on rational evaluation, which can be further subdivided into influence legitimacy, exchange legitimacy and dispositional legitimacy according to different evaluation objects and perspectives. The legitimacy of the law is based on the judgment of the correctness of the act, which is divided into the procedural legitimacy, consequential legitimacy and structural legitimacy. Scott and Suchman's division of the legitimacy of the organization was followed by the later scholars. Although some scholars have used its modified use, such as Greenwood specifically defined the legitimacy of the profession; Archibald suggests that cognitive legitimacy and normative legitimacy be referred to as the legitimacy of culture; Zilomerman \& Zeitz (2002) classifies the legitimacy of a start-up firm based on the classification of the previous two scholars and joined the industry legitimacy dimension, but Scott and Suchman's legitimacy dimension is still the mainstream of academic research, become the basic theory of related research, each scholar division of the legitimacy dimension can be summarized as Table 3 .

\section{Legalization Strategy}

In the academic community to use the institutional legitimacy perspective and strategic legitimacy perspective to study the legitimacy of the further, more and more scholars have begun to note that the organization under the constraints of legitimacy is not completely passive, can take the initiative to take legal behavior to obtain legitimacy, and then a series of strategic actions on the legitimacy of organizational research-that is, legalization strategy. (Maurer, 1971 [22], Suchman, 1995 [3], Zimmerman \& zeitz, 2002 [42], Tornikoski \& Newbert, 2007 [46]).

Table 3. Legitimacy dimension division.

\begin{tabular}{|c|c|c|c|c|c|c|c|}
\hline $\begin{array}{c}\text { The source } \\
\text { of the } \\
\text { literature }\end{array}$ & $\begin{array}{l}\text { Singh } \\
(1986)\end{array}$ & $\begin{array}{c}\text { Aldrich \& } \\
\text { Fiol (1994) }\end{array}$ & $\begin{array}{c}\text { Scott } \\
(1995)\end{array}$ & \multicolumn{2}{|c|}{ Suchman (1995) } & $\begin{array}{c}\text { Greenwood } \\
\text { (2002) }\end{array}$ & $\begin{array}{c}\text { Archibald } \\
(2004)\end{array}$ \\
\hline \multirow{7}{*}{$\begin{array}{l}\text { Legitimacy } \\
\text { dimension }\end{array}$} & \multirow{3}{*}{$\begin{array}{c}\text { Internal } \\
\text { legitimacy }\end{array}$} & \multirow{6}{*}{$\begin{array}{c}\text { Social and } \\
\text { political } \\
\text { legitimacy }\end{array}$} & \multirow{3}{*}{$\begin{array}{l}\text { Regulatory } \\
\text { legitimacy }\end{array}$} & $\begin{array}{c}\text { Transaction } \\
\text { legitimacy }\end{array}$ & \multirow{3}{*}{$\begin{array}{l}\text { Effectiveness } \\
\text { of legitimacy }\end{array}$} & & \multirow{3}{*}{$\begin{array}{l}\text { Regulatory } \\
\text { legitimacy }\end{array}$} \\
\hline & & & & $\begin{array}{l}\text { Influence } \\
\text { legitimacy }\end{array}$ & & & \\
\hline & & & & $\begin{array}{l}\text { Attribute } \\
\text { legitimacy }\end{array}$ & & & \\
\hline & \multirow{4}{*}{$\begin{array}{l}\text { External } \\
\text { legitimacy }\end{array}$} & & \multirow{3}{*}{$\begin{array}{l}\text { Normative } \\
\text { legitimacy }\end{array}$} & $\begin{array}{c}\text { Results } \\
\text { Legitimacy }\end{array}$ & \multirow{3}{*}{$\begin{array}{c}\text { Moral } \\
\text { legitimacy }\end{array}$} & Expert & \multirow{4}{*}{$\begin{array}{l}\text { - Cultural } \\
\text { legitimacy }\end{array}$} \\
\hline & & & & $\begin{array}{c}\text { Process } \\
\text { legitimacy }\end{array}$ & & legitimacy & \\
\hline & & & & $\begin{array}{l}\text { Structural } \\
\text { legitimacy }\end{array}$ & & $\begin{array}{c}\text { General } \\
\text { specification } \\
\text { legitimacy }\end{array}$ & \\
\hline & & $\begin{array}{l}\text { Cognitive } \\
\text { legitimacy }\end{array}$ & $\begin{array}{l}\text { Cognitive } \\
\text { legitimacy }\end{array}$ & & $\begin{array}{l}\text { Cognitive } \\
\text { legitimacy }\end{array}$ & & \\
\hline
\end{tabular}

Source: Author finishing. 
The legalization strategy, that is, the organization in order to be consistent with the institutional environment recognized by the stakeholders, to take a series of changes in their own structure and behavior of strategic initiatives to obtain legitimacy. Some organizations are considered to be self-disciplined because they have the resource capacity recognized by the various interest groups, especially key interest groups. But the vast majority of organizations in accordance with the expectations of stakeholders and their own resources, with the institutional environment and their own resources to match the strategic behavior, which has been recognized by the relevant interest groups and access to strategic legitimacy [46]. According to Suchman's (1995) [3] division, the organization of the legalization strategy can be divided into compliance legalization strategy, selective legalization strategy and manipulation of legalization strategy. The socalled compliance-based legalization strategy, refers to the organization in strict accordance with the existing standards and concepts, systems, norms to obtain interest groups recognition and acceptance. Enterprises use the familiar language, methods and patterns to obtain the recognition of customers and other stakeholders. The organization found that as long as a well-behaved, consistent with and adhere to the existing institutional framework, it can easily obtain organizational legitimacy. Enterprises adopting this strategy will strictly abide by the existing cultural order and system in production and business activities, and do not easily transcend the accepted cognitive framework [47]. The so-called selective legalization strategy, refers to the choice of enterprises conducive to their own development of the subdivision environment (more acceptable or more popular system area) to obtain the relevant interest groups recognition and acceptance. This is because the business is very clear that not all of the business activities are recognized by the external environment, this time a wise business will choose a most friendly market for their own, and thus get organizational legitimacy. The so-called manipulation strategy, refers to the impact, control or change the existing system, norms, standards and concepts to obtain stakeholder recognition and acceptance. Showing the enterprise more initiative. The core of this legalization strategy is to take the initiative, with its passive to adapt to the environment to get legitimacy, not as good as change and manipulate the environment to take the initiative to fight for legitimacy. In general, it is extremely difficult and risky to implement this strategy, but if it is successful, the benefits are far better than the first two legalization strategies. The strategies that can be adopted in the organization's legalization strategy are shown in Table 4.

Since then, Zimmerman \& Zeitz (2002) [42] proposed four kinds of legalization strategies based on the three legalization strategies of Suchman (1995), such as compliance, selection, manipulation and creation. Creative legalization strategy requires enterprises to create a new institutional environment with great concentration, cultivate new cognitive basis and beliefs. When the existing system does not match the cognitive basis of the enterprise, the enterprise needs to create new patterns, practice and cognitive beliefs to obtain legitimacy. This legalization strategy is more difficult to implement, but once successful, the return 
Table 4. Strategies that can be adopted in the organization's legalization strategy.

\begin{tabular}{|c|c|c|c|}
\hline & Dependent type & Select type & Manipulation type \\
\hline \multirow{4}{*}{$\begin{array}{l}\text { Regulatory } \\
\text { legitimacy }\end{array}$} & Obey the request & Choose to market segments & Institutionalized \\
\hline & - Obey the requirements of the competent & - Choose a friendly system area & - Adhere to promote \\
\hline & authorities such as the government & - Choosefriendly collaborators & - Standardization \\
\hline & - Subject to stakeholder cooperation & & \\
\hline \multirow{4}{*}{$\begin{array}{l}\text { Normative } \\
\text { legitimacy }\end{array}$} & Obey the specification & Select the range of activities & Convince \\
\hline & - Obey social norms & - Select the activity content & - Prove successful \\
\hline & - Obey the values of the public & - Select the target audience & - Change the concept of \\
\hline & - Subject to professional norms & & public opinion \\
\hline \multirow{3}{*}{$\begin{array}{l}\text { Cognitive } \\
\text { legitimacy }\end{array}$} & Obey the existing model & Select the logo & Advertising \\
\hline & - Follow the example of advanced & - Choose corporate culture slogan & - Product advertising \\
\hline & - Obey the standard & - Select the certification system & • Image advertising \\
\hline
\end{tabular}

Source: Suchman M C. Managing legitimacy: Strategic and institutional approaches. Academy of Management Review, 1995, 20 (3): 571-610. Zimmerman M A, Zeitz G J. Beyond Survival: Achieving New Venture Growth By Building Legitimacy. Academy of Management Review, 2002, 27 (3): 414-431.

is far ahead of the three legalization strategies. Oliver (1991) [34] in accordance with the level of initiative, to legalize strategy is divided into five, and is accompanied by 15 kinds of tactics, as shown in Table 5.

There are many studies on the strategy of legitimacy, and now the mainstream of the academic community is basically the model of three legalization strategies (compliance, choice, manipulation) and Oliver's five legalization strategies (acquiescence, compromise, avoidance, resistance and manipulation).

\section{Research Outlook}

The research and development of organizational legitimacy in institutional theory are the result of cross-infiltration of management, psychology, behavior and sociology. Research on the legitimacy of the organization in the near future encountered a bottleneck; the development rate is relatively slow. A large part of the reason is that the legitimacy of the organization is too focused on qualitative research, scholars are willing to carry out quantitative research, but the special nature of organizational legitimacy making qualitative research is very complex and difficult, or even inoperable. In view of this, this paper believes that the legitimacy of the relevant research has the following breakthrough:

To improve the measurement of the legitimacy of the organization, the researchers need to develop a scale to measure the legitimacy of the organization of this idea; of course, this is not easy. However, once the development of the academic community on the organization recognized the legitimacy of the scale, the study of the legitimacy of the organization will be epic breakthrough.

To improve the organization of the micro-mechanism of the legitimacy of the study, too many studies have pointed out the way in which organizational legitimacy is acquired and the strategic path. But in a specific area of organizational legitimacy formation process, evolution mechanism, mechanism of action and other micro-researches are very few. Such as the interaction process of the firm 
Table 5. Enterprise legalization strategy under different degree of initiative.

\begin{tabular}{|c|c|c|c|c|}
\hline Initiative & strategy & Connotation & Tactics & Example \\
\hline \multirow{3}{*}{ Low initiative } & acquiescence & $\begin{array}{l}\text { The reason for acquiescence is in a single or integrated } \\
\text { motive to enhance legitimacy, fear of being sanctioned, } \\
\text { and want to get additional resources }\end{array}$ & $\begin{array}{l}\text { habit } \\
\text { imitate } \\
\text { obey }\end{array}$ & $\begin{array}{l}\text { Follow the standard of course } \\
\text { Imitate the institutionalized example } \\
\text { Comply with rules and standards }\end{array}$ \\
\hline & compromise & $\begin{array}{l}\text { In the context of conflicting authorities, the } \\
\text { organization discovers that there are spaces in the } \\
\text { multiple scenarios that have considerable operational, } \\
\text { understand, bargain, and compromise }\end{array}$ & $\begin{array}{l}\text { balance } \\
\text { appease } \\
\text { to discuss }\end{array}$ & $\begin{array}{c}\text { Balance the expectations of multiple } \\
\text { stakeholders } \\
\text { To appease and be motivated } \\
\text { Negotiate with stakeholders }\end{array}$ \\
\hline & avoid & $\begin{array}{l}\text { Organizations tend to try to hide themselves and } \\
\text { prevent certain parts of the organization from } \\
\text { being influenced by the system requirements } \\
\text { that should or must comply }\end{array}$ & $\begin{array}{l}\text { hide } \\
\text { buffer } \\
\text { divorced }\end{array}$ & $\begin{array}{l}\text { Camouflage compliance } \\
\text { Relax system dependency } \\
\text { Change the goal, activity or field }\end{array}$ \\
\hline \multirow{2}{*}{$\begin{array}{l}\text { Higher } \\
\text { initiative }\end{array}$} & resistance & $\begin{array}{l}\text { If the organization's norms or gains are in substantial } \\
\text { divergence from the organization attempting to impose } \\
\text { its requirements, the organization takes a rebellious act }\end{array}$ & $\begin{array}{l}\text { ignore } \\
\text { challenge } \\
\text { attack }\end{array}$ & $\begin{array}{c}\text { Ignore the specific standards and } \\
\text { values } \\
\text { Compete for regulatory right } \\
\text { Attack the source of stress }\end{array}$ \\
\hline & manipulate & $\begin{array}{l}\text { The organization tries to cooperate with the system } \\
\text { activists to influence or even control the environment }\end{array}$ & $\begin{array}{l}\text { by-election } \\
\text { influences }\end{array}$ & $\begin{array}{l}\text { The introduction of strong } \\
\text { Shape values and standards }\end{array}$ \\
\hline
\end{tabular}

Source: According to Oliver C. Strategic responses to institutional processes. Academy of management review, 1991, 16 (1): 145-179.

and its stakeholders, and how the actors' motivations are influential, etc. [21]. The study of the micro-mechanism of the legitimacy of this organization will make it more operational.

\section{References}

[1] Romanelli, E. (1991) The New Institutionalism in Organizational Analysis. In: Powell, W.W. and Di Maggio, P.J., Eds., The New Institutionalism in Organizational Analysis, University of Chicago Press, 387-393.

[2] Du, Y.Z. and Zhang, Y.L. (2009) New Enterprise Mortality Rate Theory Review and Legal Growth Research Outlook. Science and Science and Technology Management, 30, 136-142.

[3] Suchman, M.C. (1995) Managing Legitimacy: Strategic and Institutional Approaches. Academy of Management Review, 20, 571-610.

[4] Scott, W.R. (2001) Institutions and Organizations. Sage Publications.

[5] Wernerfelt, B. (1984) A Resource-Based View of the Firm. Strategic Management Journal, 5, 171-180. https://doi.org/10.1002/smj.4250050207

[6] Di Maggio, P. and Powell, W.W. (1983) The Iron Cage Revisited: Collective Rationality and Institutional Isomorphism in Organizational Fields. American Sociological Review, 48, 147-160. https://doi.org/10.2307/2095101

[7] Lu, Y. and Xu, E.M. (2009) Institutional Theory and Corporate Strategy Research. Strategic Management, 1, 14-22.

[8] Peng, M.W. (2007) Global Strategy-Bilingual Ed. Posts \& Telecom Press.

[9] Song, T.B. and Zhang, J.B. (2014) Multi-Perspective Interpretation of Strategic 
Choice of Local State-Owned Enterprises in Transitional Period. Academic Research, 1, 79-84, 160.

[10] Van Buren (2015) The Theory of Leisure Class: On the System of Economic Research. Central Compilation Council.

[11] Meyer, J.W. and Rowan, B. (1977) Institutionalized Organizations: Formal Structure as Myth and Ceremony. American Journal of Sociology, 83, 340-363. https://doi.org/10.1086/226550

[12] Lan, H., Wang, X., Wu, S. and Song, T. (2010) Influencing Factors of Market Entry Mode Based on Institutional Basis: Theoretical Model Construction and Related Research Proposition. Nankai Management Review, No. 6, 77-90, 148.

[13] Tu, Z. and Song, T. (2016) Application of Institutional Theory in the Study of Economic Organization Management-Bibliometrics Based on Web of Science. Economic Management, No. 10, 184-199.

[14] Williamson, O.E. (1975) Markets and Hierarchies. New York, 26-30.

[15] Williamson, O.E. (1985) The Economic Institutions of Capitalism. Simon and Schuster.

[16] North, D. (1990) Institutions, Institutional Change and Economic Performance. Cambridge University Press, Cambridge.

[17] North, Y. and Hua, P. (1991) Economic History of the Structure and Change. Sanlian Bookstore Shanghai Branch, Shanghai.

[18] Hall, P.A. and Taylor, R.C.R. (1996) Political Science and the Three New Institutional Experiences. Political Studies, 44, 936-957. https://doi.org/10.1111/j.1467-9248.1996.tb00343.x

[19] Ruef, M. and Scott, W.R. (1998) A Multidimensional Model of Organizational Legitimacy: Hospital Survival in Changing Institutional Environments. Administrative Science Quarterly, 43, 877. https://doi.org/10.2307/2393619

[20] Weber, M. (1958) Science as a Vocation. Daedalus, 87, 111-134.

[21] Parsons, T. (1960) Structure and Process in Modern Societies. American Journal of Sociology, 66, 5.

[22] Maurer, J.G. (1971) Readings in Organization Theory. Random House.

[23] Dowling, J. and Pfeffer, J. (1975) Organizational Legitimacy: Social Values and Organizational Behavior. Pacific Sociological Review, 18, 122-136. https://doi.org/10.2307/1388226

[24] Meyer, J.W. and Rowan, B. (1977) Institutionalized Organizations: Formal Structure as Myth and Ceremony. American Journal of Sociology, 83, 340-363.

[25] Meyer, J.W. and Scott, W.R. (1983) Organization and Environments: Ritual and Rationality. Stanford University Press, Stanford.

[26] Laumann, E.O., Knoke, D. and Kim, Y.H. (1985) An Organizational Approach to State Policy Formation: A Comparative Study of Energy and Health Domains. American Sociological Review, 50, 1. https://doi.org/10.2307/2095336

[27] Pfeffer, J. and Salancik, G.R. (1981) The External Control of Organizations: A Resource Dependence Perspective. American Journal of Sociology, 87, 23.

[28] Terreberry, S. (1968) The Evolution of Organizational Environments. Administrative Science Quarterly, 12, 590-613. https://doi.org/10.2307/2391535

[29] Zhou, X. (2003) Organization of Sociology Ten. Social Science Literature Publishing House.

[30] Guo, Y. (2006) Management of the Critical Force. China People's University Press, 
Beijing.

[31] Elsbach, K.D. (1994) Managing Organizational Legitimacy in the California Cattle Industry: The Construction and Effectiveness of Verbal Accounts. Administrative Science Quarterly, 39, 57-88. https://doi.org/10.2307/2393494

[32] Davis, P.S., Desai, A.B. and Francis, J.D. (2000) Mode of International Entry: An Isomorphism Perspective. Journal of International Business Studies, 31, 239-258. https://doi.org/10.1057/palgrave.jibs.8490904

[33] Song, T. and Wu, J. (2013) Market Segmentation Premise of the Diversification Strategy: Analysis of Central Enterprises and Local State-Owned Enterprises. Reform, No. 5, 127-136.

[34] Oliver, C. (1991) Strategic Responses to Institutional Processes. Academy of Management Review, 16, 145-179. https://doi.org/10.5465/AMR.1991.4279002

[35] Li, X.L., Ma, W., Liu, Z., et al. (2011) Entrepreneurial Orientation and Enterprise Growth from the Perspective of Legitimacy: Based on the Empirical Test of Chinese New Enterprises. China Industrial Economy, No. 8, 99-108.

[36] Zucker, L.G. (1988) Institutional Patterns and Organizations: Culture and Environment. Contemporary Sociology, 18.

[37] Cao, Z. (2005) Private Enterprises in the Organizational Structure of the Political Characteristics and Evolution-Wenzhou Case. Beijing Tianzheng Economic Research Institute, China Institutional Economics Society Preparatory Committee, China Institutional Economics Annual Selected Papers Beijing, China Economic Research Institute, China Institutional Economics Association Preparatory Committee, 25.

[38] Aguinis, H. and Glavas, A. (2012) What We Know and Do Not Know about Corporate Social Responsibility a Review and Research Agenda. Journal of Management. Official Journal of the Southern Management Association, 38, 932-968. https://doi.org/10.1177/0149206311436079

[39] Tolbert, P.S. and Zucker, L.G. (1983) Institutional Sources of Change in the Formal Structure of Organizations: The Diffusion of Civil Service Reform, 1880-1935. Administrative Science Quarterly, 28, 22-39. https://doi.org/10.2307/2392383

[40] Hannan, M.T. and Freeman, J. (1977) The Population Ecology of Organizations. American Journal of Sociology, 82, 929-964.

[41] Oliver, C. (1991) Institutional Linkages and Organizational Mortality. Administrative Science Quarterly, 36, 187-218.

[42] Zimmerman, M.A. and Zeitz, G.J. (2002) Beyond Survival: Achieving New Venture Growth by Building Legitimacy. Academy of Management Review, 27, 414-431.

[43] Singh, J.V., Tucker, D.J. and House, R.J. (1986) Organizational Legitimacy and the Liability of Newness. Administrative Science Quarterly, 31, 171-193. https://doi.org/10.2307/2392787

[44] Aldrich, H.E. and Fiol, C.M. (1994) Fools Rush in? The Institutional Context of Industry Creation. Academy of Management Review, 19, 645-670.

[45] Song, T. and Zeng, P. (2011) Multi-System Pressure and Enterprise Legitimacy Tendency Choice: A Theoretical Model. Soft Science, No. 4, 112-116.

[46] Tornikoski, E.T. and Newbert, S.L. (2007) Exploring the Determinants of Organizational Development: A Legitimacy Perspective. Journal of Business Venturing, 22, 311-335.

[47] Brannick, M.T., Salas, E. and Prince, C. (1997) Team Performance Assessment and Measurement: Theory, Methods, and Applications. Psychology Press. 
Submit or recommend next manuscript to SCIRP and we will provide best service for you:

Accepting pre-submission inquiries through Email, Facebook, LinkedIn, Twitter, etc. A wide selection of journals (inclusive of 9 subjects, more than 200 journals)

Providing 24-hour high-quality service

User-friendly online submission system

Fair and swift peer-review system

Efficient typesetting and proofreading procedure

Display of the result of downloads and visits, as well as the number of cited articles Maximum dissemination of your research work

Submit your manuscript at: http://papersubmission.scirp.org/

Or contact ojbm@scirp.org 